\title{
Biobleaching of banana fibre pulp with incorporation of xylanase enzyme from Aspergillus oryzae
}

PRATIBHA BARAL, R.K. JAIN AND A.K. DIXIT

Article Chronicle :

Received :

28.02.2017;

Revised:

09.05.2017;

Accepted :

22.05.2017
ABSTRACT : The potential of extracellular xylanase produced by Aspergillus oryzae through solid state fermentation was investigated on banana fibre pulp bleaching in association with conventional bleaching with chlorine dioxide. The maximum enzyme production was obtained at $30^{\circ} \mathrm{C}$ after $48 \mathrm{hrs}$ of incubation using wheat bran substrate. Highest enzyme activity $1136 \mathrm{IU} / \mathrm{g}$ dry substrate was found under optimized condition. Banana fibre pulp were pretreated with different dose of xylanase enzyme before the conventional bleaching sequence. Xylanase pre-treatment reduce the kappa no and enhance the optical and physical properties of pulp. The maximum reduction in kappa no were 1.3 unit at the dose of $30 \mathrm{IU} / \mathrm{g}$. Xylanase treatment also improve burst index, tensile index and double fold by 11.81 per cent, 5.7 pera cent and 2.8 per cent, respectively.

HOW TO CITE THIS ARTICLE : Baral, Pratibha, Jain, R.K. and Dixit, A.K. (2017). Biobleaching of banana fibre pulp with incorporation of xylanase enzyme from Aspergillus oryzae. Asian J. Environ. Sci., 12(1): 48-52, DOI: 10.15740/HAS/AJES/12.1/48-52.

Key Words :

Aspergillus

oryzae, Xylanase,

Biobleaching,

Solid-state

fermentation

Author for correspondence :

\section{A.K. DIXIT}

Biotechnology Division, Central Pulp and Paper Research Institute Saharanpur (U.P.) India Email : dixit_ashwani@ rediffmail.com

See end of the article for Coopted authors' 